\title{
Portion Improvement of Vehicle Entry Units Through The Improvement of Express Periodic Maintenance Service Methods in Cars Workshop
}

\section{Ahmad Kholil, Aam Amaningsih Jumhur, and Sagung Rahadi}

Department of Mechanical Engineering Education, Faculty of Engineering, Universitas Negeri Jakarta, Indonesia

\section{Abstract}

This study aims to improve the specific periodic maintenance service method so that it can increase the unit entry portion per one working day in a workgroup in the car repair shop. The measurement using the standard time working group map used in the specific periodic maintenance service method before repairing was 44 minutes and 55 seconds with a total delay of 21 minutes and 10 seconds so that the unit

Corresponding Author:

Ahmad Kholil

ahamadkholil@unj.ac.id

Received: 11 January 2019

Accepted: 14 February 2019

Published: 25 March 2019

Publishing services provided by Knowledge E

(c) Ahmad Kholil et al. This article is distributed under the terms of the Creative Commons

Attribution License, which permits unrestricted use and redistribution provided that the original author and source are credited.

Selection and Peer-review under the responsibility of the 3rd ICTVET 2018 Conference Committee.

\section{G OPEN ACCESS} entry portion was 9 units per one working day. The specific periodic maintenance service method that has undergone improvements results in an equal time between completing the work process at each vehicle position between technicians $A$ and $B$ and no delay time. So that the portion of the vehicle's entry unit from before being repaired 9 units to 12 units after the repair done because the time needed to complete a periodic vehicle service work with the specific periodic maintenance service method becomes more efficient, namely 34 minutes. In other words, there an increase in entry units of 3 units or $33 \%$ per one working day for each working group.

Keywords: periodic maintenance, express, unit entry.

\section{Introduction}

The increasing need for transportation equipment in the community will not only affect the increasing number of companies engaged in the production of transportation equipment but also will have an impact on increasing competition in after-sales services. In the after-sales service sector, every company engaged in it must have an effective and efficient strategy to survive and win the competition [1].

After sales divided into four types of services, namely warranty, service services, spare parts sales, and supporting facilities. Maintaining customer satisfaction one of the right steps that can applied by companies to remain competitive and dominant 
market share in the after sales sector. To achieve this goal a Japanese-branded car repair shop in East Jakarta required to provide effective and efficient services to its customers. Companies that serve service services, service speed factors play a very dominant role along with the best and satisfying service quality [2].

Periodic maintenance service of four-wheeled vehicles in the workshop carried out every time the customer has traveled 10,000 kilometers or average time of 6 months, whichever of the two scales achieved faster by the vehicle. Because in the range of travel or time, several vehicle components must checked and maintained, even some others require replacement of components due to several factors, for example when every multiple of 20,000 kilometers of vehicle components such as nickel or brake pads must replace because wear and/or the possibility of deformation and the process requires more time [3].

Express periodic maintenance service one of the periodic maintenance service products on four- wheeled vehicles offered to customers in workshops that have very high mobility in big cities like Jakarta. Express periodic maintenance service a service product that offers periodic maintenance services for four-wheeled vehicles specifically for certain brands with a fast time because it done by two technicians who equipped with theory and work procedures so that they trained in their fields. However, from the observations there still several points in the working method which results in less efficient processing time, this can seen from the time waiting by the technicians to complete the work process. Efficient working methods in working time needed so that periodic maintenance service services run even better.

Planning the implementation of work by work procedures or Standard Operation Procedures essential, in which planning has conceptualized so that the work will become more efficient in processing time and effective on increasing the portion of the unit entry [4]. The existence of a structured concept can influence the process of implementing a regular and smooth service and can provide comfort for vehicle owners. Routine maintenance carried out by each vehicle owner to prevent the occurrence of damage that not unexpected to endanger the safety of the driver [5]. For this reason, efforts to improve periodic maintenance services need to address in order to obtain time efficiency and increase the number of repaired cars.

\section{Literature Review}

Maintenance activity carried out repeatedly with the aim that the equipment always has the same conditions as the initial state. Maintenance also did to keep equipment in a 
condition that acceptable to its users. So periodic maintenance service an activity that programmed to follow certain ways to get the agreed conditions. Maintenance activities carried out in the workshop have two categories namely preventive and corrective care [6]. Preventive maintenance intended to protect the vehicle before the equipment becomes damaged. The treatment carried out to prevent unexpected damage from occurring so that it can endanger the safety of the driver. Corrective care intended to treat vehicles that already in an extreme condition. The activity carried out maintenance and maintenance carried out after the occurrence of an abnormality symptom in the drum brake system. This activity often referred to as repair or repair activities, so that this type of maintenance activity cannot predicted when it comes [4]. Judging from the understanding that periodic maintenance service categorized into preventive care. The method of express periodic maintenance service in the workshop a method used as a basis for work instructions on periodic maintenance services of certain brands of four-wheeled vehicles quickly with the provisions: vehicle age or use a maximum of under 10 years, periodic maintenance of vehicles at a distance of 80,000 kilometers and multiples then oil change transmission, axle oil, power steering oil, and radiator water carried out by technicians who handle general service, and if damage found that can hamper the periodic maintenance service process then the work will carried on by general service technicians [3].

For vehicle repairs, a special place needed. Workshop means a place that has activities and has definite direction and goals. Based on the decree of the minister of industry and trade number 551/MPP/Kep/10/1999 the workshop was classified into three criteria, namely class 1 workshop class II workshop and class III workshop. The meanings of the three workshops as follows: Class 1 workshop a workshop that able to perform periodic maintenance work, minor repairs, major repairs, chassis and body repairs, Class 2 workshops workshops capable of periodic maintenance work, small repairs and major repairs, or types of repairs to periodic maintenance, minor repairs and repair of chassis or body, and class 3 workshops workshops capable of carrying out regular maintenance and minor repairs.

Working group map (gang chart) a diagram that describes the steps of the process or a collection of several process flow maps where each process flow map shows a workshop series in more detail and complete. The usefulness of the working group process map as follows: providing information on the flow of materials or activities of people from the beginning of the process until the last activity, giving information about the completion time of a process, knowing the amount of activity experienced by the material or person during the process, and the tools for process improvement or work 
method. The working group map contains the current work order and proposed work order wherein the workgroup process map which now contains the existing work order, while in the map the proposed work group process contains a work sequence that has adjusted or modified so that it looks different old and new, so that we can see the efficiency and effectiveness of the work as a whole.

The work group process map can analyze existing working conditions in order to obtain benefits or work process improvements such as: eliminating unnecessary operations, reducing the distance of movement from one operation to another, reducing time wasted due to waiting activities, indicate which operations should have the possibility to combined, show the steps of operation or over-checking or repetition, and show the work and location where the work carried out [7].

Work instructions according to ISO 9001; in 2000 a working mechanism document that regulates in detail and the sequence of an activity that only involves one function as supporting quality procedures or work procedures [8]. In principle, work instructions describe how one step in a procedure performed. Sometimes writing procedures very long so that the details not detailed, so it requires a more detailed and detailed explanation using work instructions. Work instructions made to explain parts of the procedure in detail.

\section{Research Methods}

In this study, the author conducted a study in one of the Japanese brand car repair shops in East Jakarta. In order to increase the portion of the unit entry through the improvement of the specific periodic maintenance service work method, in this study, an ongoing periodic maintenance service method observed. Measuring time efficiency on the work method of express periodic maintenance service. After it known the time of each stage then analyzed to improve the process sequence more efficiently. It expected that with time efficiency can increase the entry-level portion.

The data processing procedure consists of some basic processing operations that carried out in several sequences, namely:

1. Recording, that is, entering the value of the length of time from the points in the process of the work method express periodic maintenance service on the prepared worksheet, recording the process observed when needed, and finding and recording other appropriate supporting data. 
2. Duplication (duplicating), this operation the duplication of data on forms or documents into a computer so that it easier to justify if an error occurs.

3. Verifying, because usually recording a manual operation, it essential that the data that has recorded carefully examined, there may errors, the addition of supporting data or even the reduction of unnecessary data. Moreover, it's better if you confirm to the competent resource person.

4. Classification, which separates data into various categories. The category in question the processes that must carried out in a stage of the entire process of implementing express periodic maintenance service.

5. Sorting, which to sort the stages according to the work process flow and work procedures.

6. Merging, which brings together the stages in one work method that complete.

7. Calculation, which to do numerical calculations on data that has put together so that the data can read and understood in its entirety.

8. Check tables, find and retrieve data (table look-ups, searching, retrieving). This operation intends to re-evaluate the data that has obtained in order to facilitate later when searching for data when needed.

Data processing done using a working group process map (Gang Chart). Then, from the two work maps, a working map proposed, proposed by the working method of express periodic maintenance service.

\section{Results and Discussion}

\subsection{Before the proposal}

Based on the results of the preliminary study before the proposal, a working group map recorded in Table 1-4. To handle periodic service maintenance, one vehicle needed by two technicians. Each technician's activity classified according to examination activities $(P)$, input (I), transfer $(T)$, and delay $(D)$. When each activity recorded and sorted according to the sequence of Technicians $A$ and $B$. From the time the two technicians can see how long the delay time occurs in Technician A nor Technician B.

From Table 1-4, we can see that when a vehicle under (I) technician B experiences a delay of 18 minutes and 5 seconds. When vehicles above (II) the technician B again 
experience a delay of 2 minutes and 35 seconds. When a vehicle in the middle (III) the technician A experiences a delay of 20 seconds. and when a vehicle under (IV) technician A experiences a delay of 20 seconds.

TABLE 1: When the vehicle position under (I).

\begin{tabular}{|c|c|c|c|c|c|c|c|c|c|c|c|c|}
\hline \multirow{2}{*}{ No } & \multirow{2}{*}{ TECHNGCAN A } & \multicolumn{4}{|c|}{ ACTIVITY } & \multirow{2}{*}{ TIME } & \multirow{2}{*}{ TECHNICAN B } & \multicolumn{4}{|c|}{ ACTIVITY } & \multirow{2}{*}{ TIMEE } \\
\hline & & $\bar{P}$ & $\mathrm{I}$ & $\bar{T}$ & $\bar{D}$ & & & $\bar{p}$ & $\bar{I}$ & $\mathbf{T}$ & $\bar{D}$ & \\
\hline 1 & POSITION OF VEHICLE BELOW & & & 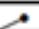 & & $0,00: 00$ & POSITION OF VEHICLE BELOW & & & 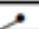 & & $0: 00: 00$ \\
\hline 2 & Check, the FR-LH door & & T & & & $0.00: 05$ & Check the trunk lid backdoor & & 7 & & & $0: 00: 10$ \\
\hline 3 & Check the seat belt FR-LH & & 6 & & & $0.00: 05$ & Check RR-RH door & & 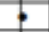 & & & $0: 00: 05$ \\
\hline 4 & Check RR-LH door & & ! & & & $0.00: 05$ & Check seatbelt RR-RH & & ? & & & $0: 00: 05$ \\
\hline 5 & Check seat beit RR-LH & & . & & & $0,00: 05$ & Check the FR-RH door & & b & & & $0: 00: 05$ \\
\hline 6 & Check the engine hood & & ! & & & 0.0005 & Check the FR-RH seatbelt & & b & & & $0,00: 05$ \\
\hline 7 & Install fender cover & & ! & & & $0.00: 20$ & Pull the engine hood opening lever & $<$ & & & & 0.00 .05 \\
\hline 8 & Check the shockbreaker bracket bolt & & . & & & 0,0005 & Check the brake brake function & & $>$ & & & $0: 00: 20$ \\
\hline 9 & Check the battery water level & & ! & & & $0.00: 10$ & start the engine & $<$ & & & & $0: 00: 05$ \\
\hline 10 & resenvoir & & ! & & & 0.00:10 & Check the $A C$ panel function and air flow & & 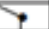 & & & $0: 00: 20$ \\
\hline 11 & Check, the level of water washer & & ! & & & $0.00: 10$ & Check steerig wheel freeplay & & , & & & $0: 00: 10$ \\
\hline 12 & Check the fuel line leak & & ! & & & $0,00: 05$ & pedals & & b & & & $0: 00: 30$ \\
\hline 13 & Check brake and clutch oil levels & & ! & & & $0.00: 05$ & Turn off the engine & $<$ & & & & $0: 00: 05$ \\
\hline 14 & Check the radiator cap & & ! & & & $0,00: 05$ & Check parking brake function (return to & & 8 & & & $0: 00: 10$ \\
\hline 15 & Check radiator leakage (pressure tester) & & 6 & & & $0.00: 20$ & Check the ras pedal & & 1 & & & $0: 00: 05$ \\
\hline 16 & Check the air filter & & b & & & $0.00: 10$ & Install the elevator on the right side of & ? & & & & $0: 00: 10$ \\
\hline 17 & Loose pressure tester & r & & & & $0.00: 05$ & Change the $A C$ filter & 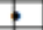 & & & & $0: 01: 00$ \\
\hline 18 & Replace spark plugs (nickel type only) & i & & & & 0.2000 & Install the left side lift of the vehicle & 6 & & & & $0: 00: 10$ \\
\hline 19 & Open the oil filling lid & i & & & & $0.00: 05$ & Remove the spare tire & 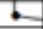 & & & & $0: 01: 00$ \\
\hline 20 & Install one man brake bleeder bottle & t & & & & $0,00-30$ & Deioy & & & & - & \\
\hline & TOTAL & 4 & 15 & 1 & 0 & $0,22 \div 45$ & TOTAL & 7 & 11 & 1 & 1 & $0: 04: 40$ \\
\hline & DELAY & & & & & $0,000: 00$ & DELAY & & & & & $0: 18: 05$ \\
\hline
\end{tabular}

TABLE 2: When the vehicle position above (II).

\begin{tabular}{|c|c|c|c|c|c|c|c|c|c|c|c|c|}
\hline \multirow{2}{*}{ No } & \multirow{2}{*}{ TECHNICAN A } & \multicolumn{4}{|c|}{ ACTIVITY } & \multirow{2}{*}{ TIME } & \multirow{2}{*}{ TECHNACAN B } & \multicolumn{4}{|c|}{ ACTIVITY } & \multirow{2}{*}{ TIMEE } \\
\hline & & $\bar{p}$ & 1 & $\mathbf{T}$ & D & & & $\mathbf{P}$ & 1 & $\mathbf{T}$ & D & \\
\hline 21 & POSITION OF ABOVE VEHICLES & & & $\rightarrow$ & & $0.00: 20$ & POSITION OF ABOVE VEHICLES & & & • & & $0: 00: 20$ \\
\hline 22 & Wear a protective helmet & +1 & & & & 0.0005 & Wear a protective heimet & 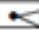 & & & & $0: 00.05$ \\
\hline 23 & Install the oil drain tank & - & & & & 0.000 .05 & Check RR-LH wear and tire damage & & 7 & & & $0: 00: 20$ \\
\hline 24 & Open the engine oil drain plug & ? & & & & $0.00-10$ & Check the parking brake cable LH & & + & & & $0: 00: 10$ \\
\hline 25 & Remove the oil filter & $\alpha$ & & & & $0.00: 20$ & Check RR-LH suspension & & + & & & $0: 00: 05$ \\
\hline 26 & Check engine oil and radiator leaks & & 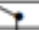 & & & $0.00: 10$ & Check RR-RH wear and tire damase & & + & & & $0: 00: 20$ \\
\hline 27 & Check the brake and elutch pipe leaks & & 6 & & & 0.0020 & Check the RH parking brake cable & & $\div$ & & & 0.00 .05 \\
\hline 28 & Replace the drive beit & 1 & & & & 0.03 .00 & Check RR·LH suspension & & + & & & $0: 00.05$ \\
\hline 29 & Install a new oil filter & 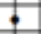 & & & & $0.00-20$ & Check the exhaust system & & + & & & $0: 00: 10$ \\
\hline 30 & Install the oil drain plug & + & & & & $0.00: 10$ & \multicolumn{2}{|l|}{ Check the wear and damage of FR-RH tires } & ! & & & $0: 00: 05$ \\
\hline 31 & Move the oil drain tank. & + & & & & 0.0005 & Check RR.LH suspension & & * & & & $0: 00: 20$ \\
\hline 32 & Remove the protective heimet & ! & & & & 0.0005 & Check RR-RH wear and tire damagge & & • & & & $0: 00.05$ \\
\hline 33 & & & & & & & Check RR-LH suspension & & b & & & $0: 00: 20$ \\
\hline 34 & & & & & & & Remove the protective helmet & $<$ & & & & 0.00 .05 \\
\hline 35 & & & & & & & Deigy & & & & $\bullet$ & \\
\hline & TOTAL & 9 & 2 & 1 & 0 & $0.05=10$ & TOTAL & 2 & 11 & 1 & 1 & $0: 02: 35$ \\
\hline & DELAY & & & & & 0,00000 & DELAY & & & & & 0:02:35 \\
\hline
\end{tabular}

Working hours The car repair shop at 8:00 a.m. to 4:00 p.m. with a 1 hour break time from 12:00 to 13:00. Only 7 hours of active employee work in one day. Procedurally, the time needed to complete one-time express periodic maintenance service 45 minutes (rounding from 44 minutes and 55 seconds). So that the portion of the periodic maintenance service for each technician 9 units/day.

\subsection{After the proposal}

When the vehicle in the 'under (I) position, technician B experiences a delay of 18 minutes and 5 seconds which should not occur, as a solution or proposal there several 
TABLE 3: When the vehicle positioned in the middle (III).

\begin{tabular}{|c|c|c|c|c|c|c|c|c|c|c|c|c|}
\hline \multirow{2}{*}{ no } & \multirow{2}{*}{ TECHEECIAN A } & \multicolumn{4}{|c|}{ Activitr } & \multirow{2}{*}{ TME } & \multirow{2}{*}{ TECHNICLAN B } & \multicolumn{4}{|c|}{ ACTIVIIY } & \multirow{2}{*}{ nIME } \\
\hline & & $\bar{D}$ & 1 & $T$ & D & & & D & 1 & $T$ & $\mathrm{D}$ & \\
\hline 36 & POSITIN OF VEHICLES IN THE MIDDLE & & & $\bullet$ & & $0: 00: 10$ & POSIMION OF VEHICLES IN THE MIDOLE & & & ڤ & & $0: 00: 10$ \\
\hline 37 & Check tire air pressure & & r & & & $0: 00: 10$ & Chack tire air pressure & & $?$ & & & $0.00: 10$ \\
\hline 38 & Check the wheel bearing & & A & & & $0: 00: 10$ & Chesk the wheal bearing & & d & & & $0,00: 10$ \\
\hline 39 & $\begin{array}{l}\text { Remove the wheel (then the balancing } \\
\text { process) }\end{array}$ & & & & & $0: 00: 10$ & $\begin{array}{l}\text { Remove the wheel (then the baloncing } \\
\text { process) }\end{array}$ & 6 & & & & $0.00: 10$ \\
\hline 40 & Install one man vacum bleeder & $\alpha$ & & & & $0: 00: 10$ & Install one man vacum bleeder & $\alpha$ & & & & $0.00: 10$ \\
\hline 41 & Check shockbreaker & & 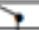 & & & $0: 00: 05$ & Check shockibresker & & $\mathrm{T}$ & & & $0: 00: 05$ \\
\hline 42 & Check for brake fluid leakage & & 6 & & & $0: 00: 05$ & Check for brake fluid leakage & & t & & & $0.00: 05$ \\
\hline 43 & Chesk the brake pad thickness and clean it & & 6 & & & $0: 00: 30$ & Chesk the brake pad thickness and clean it & & ? & & & $0.00: 30$ \\
\hline 44 & Check the thickness and thickness of the & & ! & & & $0: 05: 00$ & Check the thickness and thickness of the & & d & & & $0: 05: 00$ \\
\hline 45 & Check sealpiston leakfront brakes & & to & & & $0: 00: 10$ & Check sealpiston leakfront brakes & & t. & & & $0.00: 10$ \\
\hline 46 & Remove one man vasum bleeder & $<$ & & & & $0: 00: 30$ & Remove one man vasum bleeder & $<$ & & & & $0,00: 30$ \\
\hline 47 & Check tire air pressure & & 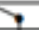 & & & $0: 00: 10$ & Chask tire air pressure & & $\bar{T}$ & & & $0.00: 10$ \\
\hline 48 & Check the wheel bearing & & 6 & & & $0: 00: 10$ & Check the wheel bearing & & S & & & $0.00: 10$ \\
\hline 49 & $\begin{array}{l}\text { Remove the whet (then the balancing } \\
\text { peocess) }\end{array}$ & & & & & $0: 00: 10$ & $\begin{array}{l}\text { Remove the wheel (then the balancing } \\
\text { process) }\end{array}$ & & & & & $0: 00: 10$ \\
\hline so & Install one man vacum bleader & $\alpha$ & & & & $0: 00: 30$ & Install one man vacum bleeder & 2 & & & & $0.00: 30$ \\
\hline 51 & Check shockbreaker & & 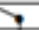 & & & $0: 00: 05$ & Chesk shockbreaker & & $\mathrm{T}$ & & & $0.00: 05$ \\
\hline 52 & Check for beake fluid leakate & & 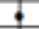 & & & $0: 00: 05$ & Check fer brake fluid leakage & & d & & & $0.00: 05$ \\
\hline 53 & Check the brake pad thickness and clean it & & + & & & $0: 00: 30$ & Check the brake pad thickness and clean it & & ? & & & $0.00: 30$ \\
\hline 54 & Chesk the thickness and thickness of the & & + & & & $0: 05: 00$ & Chesk the thickness and thiskness of the & & t & & & $0.05: \infty$ \\
\hline 55 & Check sealpiston leakfront brakes & & D & & & $0: 00: 10$ & Chesk sealpiston leakffront brakes & & t & & & $0.00: 10$ \\
\hline 56 & Remove one man vacum bleeder & a & & & & $0: 00: 10$ & Remove one man vacum bleeder & $飞$ & & & & $0.00: 10$ \\
\hline 57 & Delay & & & 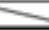 & $\bullet$ & & Check the damage and wear of spare tires & & $\bullet$ & & & $0.00: 20$ \\
\hline & TOTAL & 6 & 14 & 1 & 1 & $0,14: 10$ & TOTAL & 6 & 15 & 1 & 0 & $0: 14: 30$ \\
\hline & DELAY & & & & & $0: 00: 20$ & DELAY & & & & & $0: 00: 00$ \\
\hline
\end{tabular}

TABLE 4: When the vehicle position below (IV).

\begin{tabular}{|c|c|c|c|c|c|c|c|c|c|c|c|c|}
\hline \multirow{2}{*}{ no } & \multirow{2}{*}{ TECHEACIANIA A } & \multicolumn{4}{|c|}{ ACTIVITY } & \multirow{2}{*}{ TIME } & \multirow{2}{*}{ TECHNICLAN 8} & \multicolumn{4}{|c|}{ ACTIVITY } & \multirow{2}{*}{ TIME } \\
\hline & & $p$ & 1 & $T$ & D & & & p & 1 & $T$ & 0 & \\
\hline 58 & POSITION OF VEHICLE BELOW & & & - & & $0: 00: 10$ & POSITION OF VEHICLE BELOW & & & . & & $0: 00: 10$ \\
\hline 59 & Remove the brake bleeder bottle & 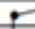 & & & & $0: 00: 10$ & Enter the spare tire arain & $\leftarrow$ & & & & $0: 01: 00$ \\
\hline 60 & Fill the enpine oil and replace the lid & ! & & & & $0.01: 00$ & Pull the parking brake lever & i & & & & $0: 00: 10$ \\
\hline 61 & start the engine & ! & & & & $0: 00: 10$ & Fasten the FR.LH wheel & i & & & & $0: 00: 10$ \\
\hline 62 & Turn off the engine & 2 & & & & $0: 00: 05$ & Fasten the FR.RH wheel & \& & & & & $0: 00: 10$ \\
\hline 63 & Check engine oill level & & $>$ & & & $0.00: 10$ & Remove the litt from the ripht and left side of & ? & & & & $0: 00: 20$ \\
\hline 64 & Remove the fender cover & ? & & & & $0: 00: 10$ & Fasten RR-LH wheels & \& & & & & $0: 00: 10$ \\
\hline 65 & Close the engine hood & - & & & & $0: 00: 05$ & Fasten the RR-RH wheel & ¿ & & & & $0: 00: 10$ \\
\hline 66 & Delay & & & & $\rightarrow$ & & & & & & & \\
\hline & TOTAL & 6 & 1 & 1 & 1 & $0: 02: 00$ & TOTAL & 7 & 0 & 1 & 0 & $0: 02: 20$ \\
\hline & DELAY & & & & & $0: 00: 20$ & DELAY & & & & & $0: 00: 00$ \\
\hline
\end{tabular}

points from the process done by technician A to transferred and divided to technician $B$ and there additional points that done to technician $B$, namely the rearview mirror, so that the time taken by technicians $A$ and $B$ will the same, namely 13 minutes and 35 seconds. We can see the description in Table 5.

When the vehicle in the position above, technician B experiences a delay of 2 minutes and 35 seconds which should not occur, as a solution or proposal there several points from the process that done by technician A which will transferred and divided to technician $B$ and there additional points did to technician $B$, which checking the power steering oil leakage, so the time taken by technicians $A$ and $B$ will the same, namely 3 minutes and 35 seconds. We can see the description in Table 6.

When the vehicle in a position in the middle of technician A experiences a delay of 20 seconds which should not occur, as a solution or a suggestion there a point from the process done by the technician $\mathrm{B}$ who will moved to the part when the vehicle under (IV), i.e., damage check and the wear of spare tires, so the time taken by technicians $A$ and $\mathrm{B}$ will the same, which 14 minutes. We can see the description in Table 7. 
TABLE 5: Proposed when the vehicle position above (I).

\begin{tabular}{|c|c|c|c|c|c|c|c|c|c|c|c|c|}
\hline \multirow{2}{*}{ No } & \multirow{2}{*}{ TECHNICIAN A } & \multicolumn{4}{|c|}{ ACTIVITY } & \multirow{2}{*}{ TIME } & \multirow{2}{*}{ TECHNICIAN B } & \multicolumn{4}{|c|}{ ACTIVITY } & \multirow{2}{*}{ TIME } \\
\hline & & $\bar{P}$ & $T$ & $\bar{T}$ & $\mathbf{D}$ & & & $\bar{P}$ & $T$ & $\bar{T}$ & $\mathbf{D}$ & \\
\hline 1 & POSITIONOF VEHICLE EELOW & & & $\infty$ & & $0.00: 00$ & POSITIONOF VEHICLE BELOW & & & 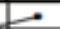 & & $0.00: 00$ \\
\hline 2 & Check the engine hood & & 7 & & & $0.00: 05$ & Pull the engine hood opening lever & - & & & & $0.00-05$ \\
\hline 3 & install fender cover & $<$ & & & & $0.00: 20$ & stant the engine & 2 & & & & 0.00005 \\
\hline 4 & Check the fuel line leak & & r & & & 0.00 .05 & Check the $A C$ panel function and bit flow & & 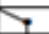 & & & 0.00 .20 \\
\hline 5 & Cheok brake and olutch oil levels & & 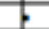 & & & $0: 00: 05$ & Check the brake be ake function & & + & & & 0.00 .20 \\
\hline 6 & Check the battery water level & & t & & & $0,00: 0$ & pedals & & + & & & $0: 00: 05$ \\
\hline 7 & \multicolumn{2}{|c|}{ Check the radistor water level of the teservoir } & ; & & & $0,00: 0$ & Check steerig wheet freeplyg & & 5 & & & $0,00: 00$ \\
\hline 8 & Cheok the level of water vasher & & 1 & & & $0,00: 10$ & Turn off the engine & $\leq$ & & & & $0,00.05$ \\
\hline 9 & Open the oil filling lid & ? & & & & $0.00: 05$ & free position] & & $\overline{7}$ & & & $0,00: 0$ \\
\hline 10 & Replace spark plugs (nickel type only] & t & & & & $0: 12: 25$ & Check the gas pedal & & t. & & & 0.00 .05 \\
\hline$\pi$ & & & & & & & Check the rearview milror & & $t$ & & & $0,00: 15$ \\
\hline 12 & & & & & & & Check the FR-Findoor & & $t$ & & & 0,00005 \\
\hline 13 & & & & & & & Check the FR.FH sestbelk & & 5 & & & 0.00 .05 \\
\hline 14 & & & & & & & wehicle & $<$ & & & & $0,00: 10$ \\
\hline 15 & & & & & & & Check FR-RH door & & 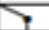 & & & $0.00: 05$ \\
\hline 16 & & & & & & & Check sesebelk RiR.FiH & & $t$ & & & 0.00 .05 \\
\hline 17 & & & & & & & Check the trunk lid backdoor & & 1 & & & $0.00: 05$ \\
\hline 18 & & & & & & & Remove the spare tire & $<$ & & & & 0,0100 \\
\hline 19 & & & & & & & Check PR.LH door & & 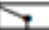 & & & 0.00 .05 \\
\hline 20 & & & & & & & Check seat belk RR.LH & & $t$ & & & 0.000 .05 \\
\hline 21 & & & & & & & Check the FR.LH doot & & + & & & 0.00 .05 \\
\hline 22 & & & & & & & Check the sess belk FR.LH & & J & & & $0.00: 05$ \\
\hline 23 & & & & & & & Change the $\mathrm{ACC}$ filtet & $?$ & & & & 0.0100 \\
\hline 24 & & & & & & & Install the left side lift of the vehicle & 5 & & & & $0,00: 10$ \\
\hline 25 & & & & & & & Check the shockbreaker bracket bolt & & 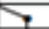 & & & 0.00 .05 \\
\hline 26 & & & & & & & Check the radiator oap & & + & & & 0.00 .05 \\
\hline 27 & & & & & & & Check radiator le ak age (pressune tester) & & 6 & & & $0.00: 20$ \\
\hline 28 & & & & & & & Check the sit filtef & & 5 & & & $0,00: 10$ \\
\hline 29 & & & & & & & Loose pressure tester & $F$ & & & & $0,00.05$ \\
\hline 30 & & & & & & & Install one man brake bleeder bottle & t. & & & & 0.00 .30 \\
\hline 31 & & & & & & & Replace spack plugs (nickel tyge only) & $t$ & & & & $0,07: 35$ \\
\hline & TOTAL & 3 & 6 & $T$ & 0 & $0: 13: 35$ & TOTAL & 10 & 20 & 1 & 0 & 0:13:35 \\
\hline & DELAY & & & & & 0:00:00 & DELAY & & & & & 0:00:00 \\
\hline
\end{tabular}

TABLE 6: Proposed when the position of the vehicle below (II).

\begin{tabular}{|c|c|c|c|c|c|c|c|c|c|c|c|c|}
\hline \multirow{2}{*}{ no } & \multirow{2}{*}{ TECHNGCIAN A } & \multicolumn{4}{|c|}{ ACTIVITY } & \multirow{2}{*}{ TIME } & \multirow{2}{*}{ TECHNaCAN B } & \multicolumn{4}{|c|}{ ACTIVITY } & \multirow{2}{*}{ TIME } \\
\hline & & $\bar{P}$ & 1 & $\mathbf{T}$ & $\mathrm{D}$ & & & $\bar{P}$ & 1 & $\mathbf{T}$ & D & \\
\hline 32 & POSITION OF ABOVE VEHICLES & & & 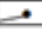 & & $0,00: 20$ & POSITION OF ABOVE VEHICLES & & & $\rightarrow$ & & $0,00: 20$ \\
\hline 33 & Wear a protective heimet & $\longleftrightarrow$ & & & & 0.00 .05 & Wear a protective heimet & $\leftarrow$ & 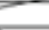 & & & $0: 00: 05$ \\
\hline 34 & Check engine oil and radiator leaks & & 7 & & & $0,00: 10$ & Check RR-LH wear and tire damage & & 7 & & & $0,00: 20$ \\
\hline 35 & Check the clutch pipe leakage & & 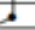 & & & $0.00: 15$ & check the parking brake cable LH & & 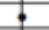 & & & $0,00: 10$ \\
\hline 36 & Replace the drive belt & 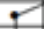 & & & & $0.03: 00$ & Check RR-LH suspension & & ! & & & $0.00: 05$ \\
\hline 37 & Remove the protestive helmet & 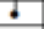 & & & & $0,00.05$ & Check RR-RH wear and tire damage & & 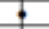 & & & $0,00: 20$ \\
\hline 38 & & & & & & & Check the AH parking brake cable & & 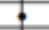 & & & $0.00: 05$ \\
\hline 39 & & & & & & & Check RR-LH suspension & & ! & & & $0: 00: 05$ \\
\hline 40 & & & & & & & Check the exhoust sistem & & ! & & & $0,00: 10$ \\
\hline 41 & & & & & & & Check the wear and damage of FR-RM tires. & & ! & & & $0.00: 05$ \\
\hline 42 & & & & & & & Check RR-LH suspension & & 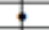 & & & $0: 00: 20$ \\
\hline 43 & & & & & & & Check RR-RH wear and tire damage & & 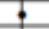 & & & $0.00: 05$ \\
\hline 44 & & & & & & & Check RR-LH suspension & & : & & & $0: 00: 20$ \\
\hline 45 & & & & & & & Oneck the leokgoe of power steering oil & & 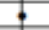 & & & $0,00: 05$ \\
\hline 46 & & & & & & & Check the brake pipe leak & & a & & & $0.00: 05$ \\
\hline 47 & & & & & & & Install the oil drain tank & T & & & & $0,00: 05$ \\
\hline 48 & & & & & & & Open the engine oil drain plus & i & & & & $0.00: 10$ \\
\hline 49 & & & & & & & Remove the oil filter & $\div$ & & & & $0: 00: 20$ \\
\hline 50 & & & & & & & Install o new oil filter & 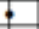 & & & & $0: 00: 20$ \\
\hline 51 & & & & & & & Install the oil drain pluz & 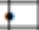 & & & & $0: 00: 10$ \\
\hline 52 & & & & & & & Move the oil drain tank & 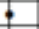 & & & & $0,00: 05$ \\
\hline \multirow[t]{3}{*}{53} & & & & & & & Remove the protertive heimet & ? & & & & $0.00: 05$ \\
\hline & & & & & & & & & & & & \\
\hline & TOTAL & 3 & 2 & 1 & 0 & $0.03: 55$ & TOTAL & 8 & 13 & 1 & 0 & $0: 03: 55$ \\
\hline \multicolumn{2}{|r|}{ DELAY } & & & & & $0,000: 00$ & DELAY & & & & & $0: 00: 00$ \\
\hline
\end{tabular}

When the vehicle in a position below (IV) technician A experiences a delay of 20 seconds which should not occur, as a solution or a suggestion there a point from the process carried out by technician B to transferred to technician A, that "Pull the parking brake lever", and there additional points made to technician B, namely checking damage and wear of spare tires, so that the time taken by technicians A and B will the same, namely 2 minutes and 10 seconds. We can see the description in Table 8. 
TABLE 7: Proposed when positioning the vehicle in the middle (III)

\begin{tabular}{|c|c|c|c|c|c|c|c|c|c|c|c|c|}
\hline \multirow{2}{*}{ no } & \multirow{2}{*}{ TECHNICAN A } & \multicolumn{4}{|c|}{ ACTIVIY } & \multirow{2}{*}{ TIME } & \multirow{2}{*}{ TEOHERAN 8} & \multicolumn{4}{|c|}{ ACTIVIY } & \multirow{2}{*}{ TIME } \\
\hline & & $\mathbf{p}$ & 1 & $\mathbf{T}$ & D & & & $\mathbf{p}$ & 1 & $\mathbf{T}$ & $\mathrm{D}$ & \\
\hline 35 & POSITION OF VEHICLES IN THE MIDDLE & & & : & & $0: 00: 10$ & DOSITION OF VEHICLES IN THE MIDOLE & & & 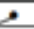 & & 0.0010 \\
\hline 37 & Check tire air pressure & & \% & & & $0.00: 10$ & Check tire air pressure & & F & & & 0.0010 \\
\hline 38 & Check the wheel bearing. & & S & & & $0.00-10$ & Check the wheel bearing & & . & & & $0.00-10$ \\
\hline 39 & Remove the wheel (then the balancing & ? & & & & $0: 00: 10$ & Remove the wheel (then the balancing & 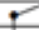 & & & & $0.00-10$ \\
\hline 40 & Install one man vacum bleeder & $\alpha$ & & & & $0,00: 10$ & Install one man vacum bleeder & 2 & & & & 0,0010 \\
\hline 41 & check shockbreaker & & i & & & 0.0005 & Check shockbreaker & & 7 & & & 0.0005 \\
\hline 42 & Check for brake fluid leakage & & ! & & & 0.00 .05 & Check for brake fluid leakare & & ! & & & 0.00005 \\
\hline 43 & Check the brake pad thickness and & & . & & & $0: 00-30$ & Check the brake pad thickness and clean & & i & & & 0.0030 \\
\hline 44 & check the thickness and thickness of & & ! & & & $0.05: 00$ & Check the thickness and thickness of the & & + & & & $0.05: 00$ \\
\hline 45 & Check seaipiston leak front brakes & & 6. & & & $0.00-10$ & Check sealpiston leak front brakes & & d & & & 0.0010 \\
\hline 45 & Remove one man vacum bleeder & $<$ & & & & $0.00-30$ & Remove one man vacum bleeder & $<$ & & & & $0.00-30$ \\
\hline 47 & Check tire air pressure & & 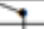 & & & $0: 00:-10$ & Check tire air pressure & & ? & & & 0,0010 \\
\hline 48 & Check the wheel bearing & & t & & & $0,00: 10$ & Check the wheel bearing & & 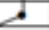 & & & 0.0010 \\
\hline 49 & Remove the wheel (then the balanting & T & & & & $0.00-10$ & Remove the wheel (then the balancing & T & & & & 0.0010 \\
\hline so & Install one man vacum bleeder & $\alpha$ & & & & $0.00-30$ & Install one man vacum bleeder & $\alpha$ & & & & $0.00-30$ \\
\hline 51 & Check shockbreaker & & 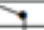 & & & 0,0005 & Check shockbreaker & & 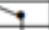 & & & 0.0005 \\
\hline 52 & Check for brake fluid leakaze & & i. & & & 0,0005 & Check for brake fluid leakare & & ! & & & 0,0005 \\
\hline 53 & Check the brake pad thickness and & & ? & & & 0.00 .30 & Check the brake pad thickness and clean & & ! & & & 0.0030 \\
\hline 54 & Check the thickness and thickness of & & i & & & $0: 05.00$ & Check the thickness and thickness of the & & i & & & $0.05=0$ \\
\hline 55 & Check sealpiston leak front brakes & & 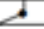 & & & $0: 00: 10$ & Check sealpiston leak front brakes & & 5 & & & 0.0010 \\
\hline 55 & Remove one man vacum bleeder & • & & & & $0,00: 10$ & Remove one man vacum bleeder & - & & & & 0.0010 \\
\hline & TOTAL & 6 & 14 & 1 & 0 & $0: 14: 10$ & TOTAL & 6 & 14 & 1 & 0 & $0: 14-10$ \\
\hline & DELAY & & & & & $0: 00: 00$ & DELAY & & & & & $0: 00000$ \\
\hline
\end{tabular}

TABLE 8: Proposed when the vehicle position below (IV).

\begin{tabular}{|c|c|c|c|c|c|c|c|c|c|c|c|c|}
\hline \multirow{2}{*}{ No } & \multirow{2}{*}{ TECHNICAN A } & \multicolumn{4}{|c|}{ ACTIVIY } & \multirow{2}{*}{ TIME } & \multirow{2}{*}{ TECHNICLAN B } & \multicolumn{4}{|c|}{ ACTINITY } & \multirow{2}{*}{ TIME } \\
\hline & & $\bar{p}$ & 1 & $\bar{T}$ & D & & & $P$ & $\overline{1}$ & $T$ & D & \\
\hline 57 & POSITION OF VEHICLE BELOW & & & $\infty$ & & $0: 00-10$ & POSITION OF VEMICLE BELOW & & & $\infty$ & & $0.00: 10$ \\
\hline 58 & Remove the brake bleeder bottle & 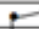 & & & & $0: 00: 10$ & Check the damaze and wear of spare tires & & 2 & & & $0.00: 20$ \\
\hline 59 & Fill the engine oil and replace the lid & t & & & & 0,0100 & Enter the spare fire again & ? & & & & $0.01: 00$ \\
\hline 60 & Pull the parking brake lever & 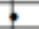 & & & & $0.00: 10$ & fasten the FR-UH wheel & 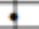 & & & & $0.00: 10$ \\
\hline 61 & start the engine & 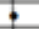 & & & & $0: 00: 10$ & Fasten the FR-RH wheel & i & & & & $0.00: 10$ \\
\hline 62 & Turn off the engine & . & & & & $0: 00: 05$ & Remove the left-hand vehicle lift & 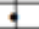 & & & & $0.00: 10$ \\
\hline 63 & Remove the right-hand vehicle lift & $a$ & & & & $0,00: 10$ & Fasten RR-LH whee is & ? & & & & $0.00: 10$ \\
\hline 64 & Check engine oil level & & $>$ & & & $0.00: 10$ & Fasten the RR-AH wheel & J & & & & $0.00: 10$ \\
\hline 65 & Remove the fender cover & ? & & & & $0: 00: 10$ & & & & & & \\
\hline 66 & Close the engine hood & ! & & & & $0: 00: 05$ & & & & & & \\
\hline & TOTAL & 8 & $\overline{1}$ & 1 & $\underline{0}$ & $0: 02: 20$ & TOTAL & 6 & 1 & 1 & 0 & $0: 02: 20$ \\
\hline & DELAY & & & & & $0: 00: 00$ & DELAY & & & & & $0: 00: 00$ \\
\hline & TOTAL PEOCESS WITHOUT DELAY & & & & & $0: 34: 00$ & TOTAL PROCESS WITHOUT DELAY & & & & & $0: 34: 00$ \\
\hline
\end{tabular}

From the results of the research data analysis table, we can see that during the express periodic maintenance service process both technician $A$ and $B$ have not experienced delay in other words finished at the same time, and the total time required much shorter, i.e., 34 minutes from the original 44 minutes and 55 seconds or approximately 10 minutes and 55 seconds. Then the number of unit entry per working day 12 units/working day. The portion of work using the improved periodic maintenance service express method obtained now to 12 units per one more working day 3 units of entry than the previous 9 units per one working day. If we calculate the percentage increase in unit entry portion per working day in one working group using the specific periodic maintenance service method that has fixed 33\%. The improvement of the specific periodic maintenance service method can increase the unit entry portion by 3 units per one working day or by $33 \%$ from before repairs.

In this research, the improvement of specific method periodic maintenance service produced a new work instruction that had tested and confirmed by those who have competence in their fields, namely foreman as a quality control job and at the same time as the supervisor of this research. So that the work instructions can applied directly 
to the workshop in East Jakarta or other branches through the approval of the company representative, namely the head of the workshop (workshop head).

\section{Conclusion}

Based on observations by using a working group map (gang chart) on the express periodic maintenance service method before experiencing improvement, it known that there an unbalanced division of work processes seen from the length of work time between technicians $A$ and $B$, resulting in a delay in the process time and less systematic work processes. thus causing the technician not to use the maximum time given. The measurement using the standard time working group map used in the specific periodic maintenance service method before repairing was 44 minutes and 55 seconds with a total delay of 21 minutes and 10 seconds so that the unit entry portion was 9 units per one working day. The specific periodic maintenance service method that has undergone improvements results in an equal time between completing the work process at each vehicle position between technicians $A$ and $B$ and no delay time. So that the portion of the vehicle's entry unit from before being repaired 9 units to 12 units after the repair done because the time needed to complete a periodic vehicle service work with the specific periodic maintenance service method becomes more efficient, namely 34 minutes. In other words, there an increase in entry units of 3 units or 33\% per one working day for each working group.

\section{Acknowledgement}

The authors would like to thank their colleague for their contribution and support to the research. They are also thankful to all the reviewers who gave their valuable inputs to the manuscript and helped in completing the paper.

\section{References}

[1] M. J. Bitner et al., "Developing a car maintenance service concept for business customers - a case study of Veho Autotalot Oy," Park. ..., vol. 50, no. 3, pp. 66-94, 2008.

[2] P. Kotler and K. L. Keller, Marketing Management, vol. 22, no. 4. 2009.

[3] Nissan, "2016 Service and Maintenance Guide Table of Contents Owner 'S Literature Information," 2016. 
[4] G. Ravnestad, S. S. Panesar, D. Kayrbekova, and T. Markeset, "Improving Periodic Preventive Maintenance Strategies Using Condition Monitoring Data," Adv. Prod. ..., pp. 260-267, 2012.

[5] A. Grigoriev, J. van de Klundert, and F. C. R. Spieksma, "Modeling and solving the periodic maintenance problem," Eur. J. Oper. Res., vol. 172, no. 3, pp. 783-797, 2006.

[6] R. L. Higgins, Maintenace Engineering Handbook. 2002.

[7] R. S. Hussain, K. Ruikar, M. P. Enoch, N. Brien, and D. Gartside, "Process mapping for road works planning and coordination," Built Environ. Proj. Asset Manag., vol. 7, no. 2, pp. 157-172, 2017.

[8] A. Parida and U. Kumar, "Maintenance productivity and performance measurement," Handb. Maint. Manag. engeneering, pp. 17-41, 2009. 